\title{
A hálapénzzel kapcsolatos szokások a magyar egészségügyi szakdolgozók körében
}

\author{
Julesz Máté dr. - Kereszty Éva Margit dr. \\ Szegedi Tudományegyetem, Általános Orvostudományi Kar, Igazságügyi Orvostani Intézet, Szeged
}

Bevezetés: Magyarországon 2021. január 1-jétôl a hálapénz minden formájának adása és elfogadása büncselekmény, kivéve a legföljebb a minimálbér 5\%-át ( 8370 forintot) elérő ajándékot. Míg a tilalmat az orvosok esetében jelentős béremelés kompenzálja, addig a szakdolgozók korábban is kevéssé vizsgált hálapénzjuttatásának helyzetére és megváltozására vonatkozóan alig vannak adatok.

Célkitüzés: A szakdolgozói hálapénz 2020 végi kiinduló helyzetének feltárása és az új jogszabályi előírások becsülhető hatásainak vizsgálata a szakdolgozók által nyújtott információ alapján.

Módszer: 2020 őszén 167 egészségügyi szakdolgozó kérdőíves felmérése történt meg a Szegedi Tudományegyetem Szent-Györgyi Albert Klinikai Központjában a hálapénzadás motivációinak, formáinak és körülményeinek, valamint összegének megismerése érdekében. Az eredményeket elsősorban leíró statisztikai formában elemeztük, különös tekintettel a mưtéti, a belgyógyászati és a gyermekgyógyászati szakterületek között mutatkozó különbségekre; és öszszevetettük az új törvény hatására várható változásokkal.

Eredmények: A 167 válaszadóból 93-an mútéti/operatív területen, 54-en belgyógyászati jellegú területen, 18-an pedig a gyermek/ifjúsági ellátásban dolgoznak. Mindegyik szakterületen megjelent a hála mellett a korrupciós célú juttatás, de ezzel és a hálapénzjelenséggel legkevésbé a gyermekgyógyászati terület volt érintett. A nagyobb értékú ajándék ritka, de a kisebb értékű rendszeresen alkalmazott juttatás. Egy hét benntartózkodás esetén a válaszadók átlagosan 10851 forintot (36 USD) kaptak hálapénzként, míg egy-egy alkalommal 5326 forintot (18 USD). Az öszszegek - hasonlóan az orvosi hálapénzhez - jelentős eltérést mutattak az egyes területek között, a mútéti szakmákban pedig meghaladták az új törvényi korlátot. A magánellátásban kapott hálapénz kisebb arányú, a munkahelyen kívül átadott juttatás pedig kifejezetten ritka.

Következtetés: A korrupciós célú hálapénz az egészségügyi szakdolgozói szférában ugyan jelen van, de nem jellemző. A szakdolgozóknak juttatott hálapénz büntetőjogi szankcionálását nem kompenzálja az orvosokéhoz hasonló béremelés. A pénzbeli juttatás ajándéktárgy formájában történő juttatása minden területen jelent veszteséget, a műtéti területen az értékben kifejezett veszteség is jelentősebb lehet. A büntetőeljárási fenyegetettség nem elegendő a magyarországi hálapénzrendszer megszüntetéséhez, további társadalompolitikai intézkedések szükségesek az egészségügyi dolgozók és a betegek attitúdjének megváltoztatásához.

Orv Hetil. 2021; 162(41): 1658-1668.

Kulcsszavak: hálapénz, egészségügyi szakdolgozók, ajándéktárgy, korrupció, Magyarország

\section{The customs of acceptance of informal payments among Hungarian nurses}

Introduction: In Hungary, since January 1st, 2021, the giving and acceptance of all forms of informal payments constitute a crime, except for gifts of a value of no more than $5 \%$ of the minimal monthly salary. While in the case of physicians, a pay rise compensates the loss of revenue, we hardly have data on the nurses' attitude in relation to the acceptance of informal payments.

Objective: We intend to uncover the situation of informal payments at the end of 2020 and to examine the effects of the new legal regulation, based on information from nurses.

Method: In the fall of 2020, we questioned 167 nurses in the Albert Szent-Györgyi Health Center of the University of Szeged, Hungary, in order to highlight the motivations, forms, circumstances, and sums of informal payments. We analyzed the results by means of descriptive statistical methods, with special regard to the differences among surgical, internal medical and pediatric fields. We analyzed the results with a view to the new legal regulations.

Results: Out of 167 respondents, 93 work in operative field, 54 in internal medical care, and 18 in pediatric care. Besides gratitude, corruption appeared in all the three fields, however, pediatric care was the least touched by corrup- 
tion. Gifts of a higher value are rare, however, small gifts are common. The respondents received 10851 HUF (i.e., 36 USD) as informal payment from in-patients after one week, while, occasionally, 5326 HUF (i.e., 18 USD). The sums - similarly to informal payments to physicians - vary from field to field in healthcare. In the surgical field, the sums surpassed the new legal limit. Informal payments are given in private healthcare more rarely than in public healthcare. Informal payments given outside the workplace hardly ever occur.

Conclusion: The informal payment with the goal of corruption is present in the sphere of nurses, however, it is not typical. The criminal sanctioning of informal payments to nurses is not compensated by a pay rise similar to that of physicians. The fact that informal payments are substituted by gifts results in loss of revenue in all fields of healthcare, however, this loss is the most salient in the surgical field. The criminal sanctioning is not sufficient to eliminate informal payments in Hungary; further socio-political measures are to be taken with the goal to change the attitude of healthcare workers and patients.

Keywords: informal payment, nurses, gift, corruption, Hungary

Julesz M, Kereszty ÉM. [The customs of acceptance of informal payments among Hungarian nurses]. Orv Hetil. $2021 ; 162(41)$ : 1658-1668.

(Beérkezett: 2021. február 26.; elfogadva: 2021. április 10.)

\section{Rövidítések}

Btk. = Büntető törvénykönyv; COVID-19 = (coronavirus disease 2019) koronavírus-betegség 2019; Eszjt. = az egészségügyi szolgálati jogviszonyról szóló 2020. évi C. törvény; Eütv. = az egészségügyről szóló 1997. évi CLIV. törvény; KSH = Központi Statisztikai Hivatal; SZTE SZAKK = Szegedi Tudományegyetem, Szent-Györgyi Albert Klinikai Központ

Magyarországon az egészségügyi szolgálati jogviszonyról szóló 2020. évi C. törvény (Eszjt.) hatálybalépésével a Kúria korábbi álláspontja már nem lesz alkalmazható. A hálapénzadás és a hálapénz-elfogadás korrupciós bûncselekménynek minősül minden, eddig jogszerúnek elfogadott esetben is. A Büntető törvénykönyv (Btk.) 290. $\$(6)$ bek. értelmében aki egészségügyi szolgáltatás nyújtásával összefüggésben egészségügyi dolgozónak, egészségügyben dolgozónak vagy ezekre tekintettel másnak az egészségügyről szóló törvényben meghatározottak szerint jogtalan előnyt ad vagy ígér, ha súlyosabb búncselekmény nem valósul meg, vétség miatt egy évig terjedő szabadságvesztéssel büntetendő. Az aktív vesztegetővé váló beteg és a passzív vesztegetésért felelős orvos közti informális kapcsolat eddigi szokásai megváltoznak.

A Kúria említett határozata (Bhar.III.6/2015.) egy büntetőügyben kifejtette: „Hálapénz az a juttatás, amelyet az egészségügyi szolgáltatás igénybevételét követően a beteg vagy hozzátartozója hálája, köszönete jeléül a szolgáltatásban közremúködő egészségügyi dolgozónak nyújt. Ebből viszont egyértelmúen következik, hogy az elöre adott előny nem hálapénz, és az sem, amelyet a beteg nem saját elhatározásából, nem önként szolgáltat. A kért és ennek eredményeként kapott juttatás tehát nem sorolható a hálapénz kategóriájába. Kérés alatt értendő pedig minden olyan magatartás - így a célozgatás, a szokásokra történő figyelemfelhívás stb. is -, amely az önkéntességet, s ennek folytán a juttatás hálapénz jellegét kizárja."
Az új törvény a Btk.-ban foglalt fenyegetettség alól csak szúk körben ad felmentést, bizonyos esetekben a kis értékű ajándék adását és elfogadását lehetôvé teszi. Míg a közszolgáltató egészségügyben dolgozó orvosok jelentősen emelkedő illetménye okafogyottá teszi a betegtôl elfogadott külön juttatást, addig a szakdolgozók esetében a jövedelmi pozíciók változatlanul hagyása mellett érvényesül az új tilalom. A törvény egészét illetően érvényesül, hogy az egészségügyi szakdolgozók esetén a kötelezettségek/szigorítások nőnek, míg az ellentételezés nem.

Az egészségügyi törvény (Eütv.) újonnan beillesztett 138/A $\$$-a értelmében az egészségügyi dolgozó vagy az egészségügyben dolgozó a szolgáltatás nyújtását követően egy alkalommal elfogadhat a beteg vagy rá tekintettel más által ajándékként adott olyan tárgyat, amelynek értéke nem haladja meg a mindenkori minimálbér havi öszszegének 5\%-át (egyszeri, befejezett ellátás). Az egészségügyi dolgozó vagy az egészségügyben dolgozó a folyamatos benntartózkodás mellett végzett, hosszú ideig tartó egészségügyi szolgáltatás nyújtása során kéthavonta egy alkalommal elfogadhat a beteg vagy rá tekintettel más által ajándékként adott olyan tárgyat, amelynek értéke nem haladja meg a mindenkori minimálbér havi összegének 5\%-át (krónikus ellátás). Ez az összeg 2021ben 8370 Ft-ot jelent.

A hálapénz-szakirodalom a magyarországi helyzet vizsgálatakor általában az orvosok, az egyes orvosi szakterületek pozícióját vizsgálja, illetve a jelenség makrogazdasági összefüggéseit elemzi. A szakdolgozókra vonatkozó kutatások és elemzések alig találhatók. Vizsgálatunknak nem volt tárgya a korábban született tanulmányok elemzése, kizárólag egy eddig nem vagy kevéssé vizsgált terület feltárására fókuszáltunk. A jelen munkában a „nővérhálapénz” hazai és nemzetközi - elsősorban posztkommunista országokban megfigyelhető - helyzetét, jogi megítélését vizsgáljuk. 
2014-ben a KSH adatai szerint a legnagyobb összeget a kórházi orvosok kapták (4,1 milliárd forint), utána következtek a házi- és szakorvosok (2,5 milliárd), a fogorvosok (1,1 milliárd), végül az ápolók, orvosi asszisztensek, műtősök (508 millió). Az alkalmankénti legkisebb összeg az ápolóknak, orvosi asszisztenseknek, műtősöknek jutott: átlagosan 2000 forint volt, ami az összes hálapénztömegen belül enyhén növekvő arányt mutatott 2010-et követően (5,8\%-ról 6,1\%-ra) [1].

A szülészeti tevékenység sajátos helyet foglal el a hálapénz világában. Az elmúlt években elterjedt a fogadott/ választott szülésznő (szülészeti szakdolgozó) közremüködése a választott orvos mellett. Blogok és közéleti interjúk alapján az érintett betegek beszámolói szerint a fóvárosban 30 000-50 000 Ft, a Dunántúlon 20000 $40000 \mathrm{Ft}$ a fogadott szülésznői „tarifa”.

Antal és Baba a romániai hálapénzadás kapcsán, egy 2017-2018-ban egészségügyi dolgozók körében végzett felmérés eredményeként arra a következtetésre jutottak, hogy a válaszadó egészségügyi dolgozók mintegy háromnegyede jelentős - 100\%-os vagy annál nagyobb mértékü - béremelés esetén volna hajlandó lemondani a hálapénzről. Ugyanakkor a szerzők rámutattak, hogy a hálapénzadás gyakorlata a kommunizmus idején alakult ki, és ez a gyakorlat immanensen jelen van a mai Romániában is [2].

Zandian és szerzôtársai 2019-ben arra a következtetésre jutottak, hogy nincs univerzális megoldás a hálapénz problémájára. A konkrét államban múködő egészségügyi finanszírozási formától függ, hogy milyen megoldás lehet helyben hatékony. Ilyen megoldás lehet például a hálapénz informálisból formálissá tétele vagy az egészségügyben dolgozók állam általi anyagi támogatása is [3]. Horodnic és szerzótársai 2018-ban a szomszédos Romániában folyó egészségügyi hálapénzadás gyakorlatát elemezve arra a következtetésre jutottak, hogy hálapénzt adni megszokott jelenség, bár a korrupcióra egyébként hajlamosabb betegek, valamint a vidéken élők nagyobb arányban adnak hálapénzt vagy nagy értékú ajándékot az egészségügyi szolgáltatásért, mint a többi páciens [4].

Arsenijevic és mtsai 2015-ben a Szerbiában folyó hálapénzadás gyakorlatára hívták fel a figyelmet. A válaszadóknak csak 5,7\%-a számolt be arról, hogy illegálisan hálapénzt adott az egészségügyi ellátásával összefüggésben. Sokkal többen vallották azt, hogy törvényesen fizettek: például hospitalizációjuk alkalmával az egészségügyi vagy higiéniai termékekért [5]. Radin 2013-ban a Horvátországban folyó egészségügyi hálapénzadási gyakorlat visszásságaira mutatott rá. A szerző kiemelte, hogy az egészségügyben tapasztalható korrupció az ország kommunista múltjából származó örökség. A korrupció erodálja az egészségügyi szektor hatékonyságát, és többletköltségeket okoz [6].

A hálapénzadás posztkommunista jellegét húzták alá litvániai szerzők, amikor arról számoltak be, hogy a volt szovjet tagköztársaságban, Litvániában teljesen termé- szetesnek tünő gyakorlat, hogy a betegek hálapénzt (valójában vesztegetési pénzt) fizetnek azért, hogy idejében sorra kerüljenek az orvosnál, valamint hogy jobb minőségű ellátásban részesüljenek. A litvániai szerzők eredményei arra engednek következtetni, hogy a litvániai lakosság valójában nem is szeretné legálissá tenni a hálapénzadást. Litvániában ugyan van állam által finanszírozott egészségügyi ellátórendszer, de az egészségügyben dolgozók alacsony bérezése itt is szükségessé teszi a hálapénzadást [7].

A hálapénzt Magyarországon az alacsony egészségügyi bérek kompenzálására vagy kiváltságok elérése céljából adják, és a betegek is érzik ennek korrupciós jellegét [8]. A kiváltságok eléréséhez kulcsszereplő lehet az egészségügyi szakdolgozó, aki például előbbre adhat időpontot a páciensnek, vagy például valamely komfortemelő szolgáltatást nyújthat. Az orvosnak adott hálapénz nagyobb összegü, mint az egészségügyi szakdolgozónak adott hálapénz, de sokszor az utóbbival lehet ténylegesen elérni valamely privilégiumot. Éppen ezért az egészségügyi szakdolgozókat is érzékenyen érinti a hálapénz- és ajándékrendszer átalakítása.

Két svédországi kutató, Holmberg és Rothstein, arra a következtetésre jutott, hogy míg a szegényebb országokban a lakosság több mint $80 \%$-a találkozott már a hálapénz problémájával, a gazdagabb országok egészségügye is mutat diszfunkcionalitást. A gazdagabb országokban olyan típusú hálapénzadást, mint például a posztkommunista államokban, nem látunk, de a túlszámlázás és más jogellenes gyakorlatok a tehetősebb országok egészségügyére is rányomják a bélyegüket [9].

Williams és Horodnic 2018-ban arra a posztkommunista országokbeli jelenségre hívták fel a figyelmet, hogy a hálapénz mint informális jelenség a jog által szabályozott intézmények diszfunkcionális múködéséből ered. A közép- és kelet-európai országokban a hálapénz erre az aszimmetrikus múködésre vezethető vissza [10].

Balázs Péter 2019-ben az Orvosi Hetilapban így fogalmazott: „Minden közfinanszírozási modellünket külföldről másoltuk, majd következetesen figyelmen kívül hagytuk, hogy az eredeti rendszereket nem lehet tetszés szerint manipulálni. Következetesen elkövettük a közös bűnt, hogy gátlástalanul alacsony szinten számoltunk az orvosi munkadíjakkal, és ellenségesen viselkedtünk a magánfinanszírozással szemben" [11].

A Magyar Egészségügyi Szakdolgozói Kamara Etikai Kódexe kimondja: „Az egészségügyi szakdolgozó hálapénzt nem kérhet, és nem tanúsíthat olyan ráutaló magatartást, amely hálapénz iránti igényt fejez ki. Az etikai normák különösen súlyos megsértésének minősül, ha az egészségügyi szakdolgozó bármilyen anyagi vagy nem anyagi eredetú juttatást kér, vagy erre utaló magatartást tanúsít a sürgősségi betegellátás során, haldokló beteg ellátása során, egészségügyi dolgozó ellátása során, és minden olyan esetben, amikor az egészségügyi ellátáshoz való hozzáférés korlátozott. Az egészségügyi szakdolgozók egymástól nem fogadhatnak el hálapénzt.” 


\section{Módszer}

2020 őszén, a COVID-19-járvány második hullámának idején [12] az SZTE SZAKK egészségügyi szakdolgozóit kérdeztük meg a hálapénzzel kapcsolatos, közelmúltbeli (az elmúlt öt évben tapasztalt) szokásaikról egy kérdőív segítségével. A kitöltés idején még nem fogadta el az Országgyúlés az Eszjt.-t, ennek a hálapénzt érintő rendelkezéseiról tervek, információk sem voltak ismertek. A kitöltés anonim és teljes mértékben önkéntes volt. A szakdolgozók a mútéti/operatív, a belgyógyászati vagy a gyermek/ifjúsági területen dolgoznak, szándékosan nem vontunk be szülészeti dolgozókat.

A kérdések a hálapénzadás motivációját, formáját és az átadási helyzetet vizsgálták, mindegyik kérdéscsoportnál a válaszadónak gyakorisági besorolást kellett kiválasztani. Az egy ellátási esemény alkalmával adott hálapénzösszeget, illetve az egy hét bennfekvést/ápolást követően adott összeget a válaszadók ezres kerekítéssel, szabad válaszként adták meg.

A válaszokat összességében és a szakterületi csoportosításnak megfelelően dolgoztuk fel, a hálapénzösszegek tekintetében átlag-, szórás- és varianciaszámítást végeztünk.

Tekintettel a mintaszámra, az eredményeket elsődlegesen a válaszadók számával jellemeztük, a tipikus magatartások meghatározásával, a százalékos arányokat elsődlegesen a trendek demonstrálására mutatjuk be. Az eredményeket táblázatba foglaltuk, illetve grafikus ábrázolást alkalmaztunk.

A kérdőív három fó részre tagozódott:

(1) A hálapénzadás okai (motivációk).

(2) A hálapénz formái (a beteg vagy hozzátartozója a háláját hogyan fejezte ki?).

(3) A hálapénzt milyen helyzetben adták?

(1) A hálapénzadás okai (motivációk):

a) Köszönetnyilvánításként. (Az egészségügyi szolgáltatás befejezése után, őszinte hálából adták?)

b) A soronkívüliség elérése céljából. (Azért adták, hogy előbb jussanak egészségügyi szolgáltatáshoz; hogy hamarabb vagy soron kívül kerüljenek ellátásra, előbbre kerüljenek a várólistán?)

c) A szakértelem elismeréseként. (Azért adták, hogy tapasztalt egészségügyi szakdolgozó végezze a beavatkozást?)

d) Privilégium szerzése. (Azért adták, hogy [a kötelezőnél] gyakrabban cseréljék az ágynemüt, vagy jobb étel, nagyobb komfort, külön szolgáltatások [például tv, internet] elérése érdekében adták?)

e) Kivételezés. (Azért adták, hogy a beteg javára az intézményi szabályoktól eltérjenek? Például a látogatási időn túl is fogadhassanak látogatót?)

f) Valamely, jog szerint egyébként is járó jogosultság tényleges elérése érdekében. (Azért adták, hogy a gyakorlatban nem érvényesülő előírások szerint kapják a szolgáltatást, például egész nap a Gyermekklinikán lévő gyermekükkel lehessenek, tudjanak a kezelőorvossal beszélni, stb.?)

g) A beteg elhunyta után a hozzátartozó adta, amiért nem neki kellett a haldoklás/halál időszakában gondoskodnia a betegről. (Azért adta a hozzátartozó, hogy önnön lelkiismeretét megnyugtassa, vagy a halottkezelés / temetkezés költségeinek velejárójaként tekintette?)

Ђ) Utasított-e vissza hálapénzt?

(2) A hálapénz formái (a beteg vagy hozzátartozója a háláját hogyan fejezte ki?):

a) Szóban vagy írásban megköszönte.

b) Kisebb értékü tárgyi ajándékot adott (például édesség, virág, házi készítésű szőttes, csemegekosár stb.).

c) Nagyobb értékű tárgyi ajándékot adott (például utazási utalvány, nemesfém ékszer, értékes mútárgy stb.).

d) Kisebb összegű készpénzt (nem több mint 5 ezer forintot) adott.

e) Nagyobb összegű készpénzt (több mint 5 ezer forintot) adott.

f) Felajánlotta a társadalmi-szakmai kapcsolatait (például tanárként korrepetálást).

g) Tapasztalatai szerint mekkora összeget/értéket juttat a beteg/hozzátartozó (egy hét benntartózkodás esetén, illetve egy-egy alkalommal)?

(3) A hálapénzt milyen helyzetben adták?

a) Munkaidőben.

b) Ügyeleti időben.

c) Másodállásban a magánegészségügyben (például magánklinikán).

d) Otthonában, magánéletében felkeresve vagy ide küldve (például virágcsokrot, ajándékkosarat).

A gyakoriság minden kérdés esetében 1-től 5 fokig terjed:

- soha (1),

- évente egyszer (2),

- havonta egyszer (3),

- hetente egyszer (4),

- gyakrabban, mint hetente egyszer (5).

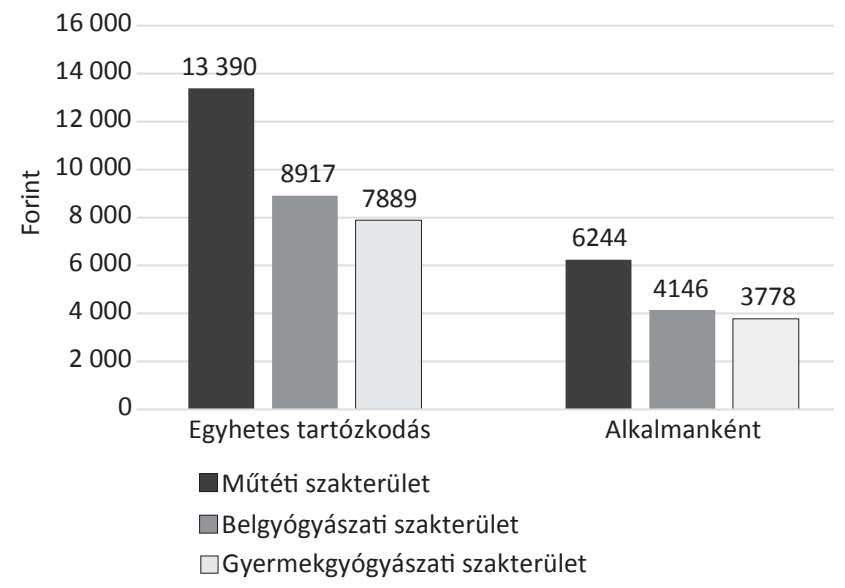

1. ábra $\quad$ Az átlagos hálapénz megoszlása az egyes szakterülettípusok sze rint 
1. táblázat |A hálapénzadás motivációi

1.M táblázat

Mütéti/operatív munkahely ( $\mathrm{n}=93$ )

\begin{tabular}{|c|c|c|c|c|c|c|}
\hline & A hálapénzadás okai (motivációk) & $=1$ & $=2$ & $=3$ & $=4$ & $=5$ \\
\hline a) & Köszönetnyilvánításként & 1 & 2 & 51 & 29 & 10 \\
\hline b) & Soronkívüliség elérése céljából & 3 & 29 & 35 & 16 & 10 \\
\hline c) & $\begin{array}{l}\text { A szakértelem elismeréseként (Azért adták, hogy tapasztalt egészségügyi szakdolgozó végezze a } \\
\text { beavatkozást?) }\end{array}$ & 12 & 41 & 16 & 17 & 7 \\
\hline d) & Privilégium szerzése & 37 & 19 & 26 & 6 & 5 \\
\hline e) & Kivételezés & 41 & 31 & 13 & 5 & 3 \\
\hline f) & Valamely, jog szerint egyébként is járó jogosultság tényleges elérése érdekében & 59 & 25 & 4 & 5 & 0 \\
\hline g) & $\begin{array}{l}\text { A beteg elhunyta után a hozzátartozó adta, amiért nem neki kellett a haldoklás/halál időszakában } \\
\text { gondoskodnia a betegről }\end{array}$ & 15 & 7 & 55 & 16 & 0 \\
\hline b) & Utasított-e vissza hálapénzt? & 20 & 9 & 45 & 12 & 7 \\
\hline
\end{tabular}

1.B táblázat

Belgyógyászati jellegű munkahely ( $\mathrm{n}=54$ )

\begin{tabular}{|c|c|c|c|c|c|c|}
\hline a) & Köszönetnyilvánításként & 0 & 0 & 19 & 26 & 9 \\
\hline b) & Soronkívüliség elérése céljából & 0 & 6 & 33 & 11 & 4 \\
\hline c) & $\begin{array}{l}\text { A szakértelem elismeréseként (Azért adták, hogy tapasztalt egészségügyi szakdolgozó végezze a } \\
\text { beavatkozást?) }\end{array}$ & 0 & 19 & 23 & 9 & 3 \\
\hline d) & Privilégium szerzése & 0 & 2 & 20 & 27 & 5 \\
\hline e) & Kivételezés & 3 & 11 & 21 & 12 & 7 \\
\hline f) & Valamely, jog szerint egyébként is járó jogosultság tényleges elérése érdekében & 10 & 15 & 21 & 4 & 4 \\
\hline g) & $\begin{array}{l}\text { A beteg elhunyta után a hozzátartozó adta, amiért nem neki kellett a haldoklás/halál időszakában } \\
\text { gondoskodnia a betegról }\end{array}$ & 4 & 18 & 24 & 7 & 1 \\
\hline b) & Utasított-e vissza hálapénzt? & 11 & 16 & 20 & 5 & 2 \\
\hline
\end{tabular}

1.GY táblázat

Gyermek/ifjúsági ellátás $(\mathrm{n}=18)$

\begin{tabular}{|c|c|c|c|c|c|c|}
\hline a) & Köszönetnyilvánításként & 0 & 3 & 11 & 3 & 1 \\
\hline b) & Soronkívüliség elérése céljából & 6 & 6 & 4 & 2 & 0 \\
\hline c) & $\begin{array}{l}\text { A szakértelem elismeréseként (Azért adták, hogy tapasztalt egészségügyi szakdolgozó végezze a } \\
\text { beavatkozást?) }\end{array}$ & 9 & 6 & 2 & 1 & 0 \\
\hline d) & Privilégium szerzése & 5 & 3 & 8 & 2 & 0 \\
\hline e) & Kivételezés & 7 & 4 & 4 & 2 & 1 \\
\hline f) & Valamely, jog szerint egyébként is járó jogosultság tényleges elérése érdekében & 10 & 3 & 3 & 0 & 2 \\
\hline g) & $\begin{array}{l}\text { A beteg elhunyta után a hozzátartozó adta, amiért nem neki kellett a haldoklás/halál időszakában } \\
\text { gondoskodnia a betegról }\end{array}$ & 11 & 6 & 1 & 0 & 0 \\
\hline b) & Utasított-e vissza hálapénzt? & 2 & 2 & 1 & 3 & 10 \\
\hline
\end{tabular}

1 = soha

2 = évente egyszer

3 = havonta egyszer

$4=$ hetente egyszer

5 = gyakrabban, mint hetente egyszer

\section{Eredmények}

167 kérdőívet kaptunk vissza a válaszadóktól. Néhány megválaszolatlanul maradt kérdés előfordult a kérdőívekben, de összességében véve jól értékelhető, teljeskörüen kitöltött adatlapokat kaptunk. A beérkezett válaszokból nem került kizárásra kérdőív.

56 férfi és 109 női válaszadót azonosítottunk, szakmacsoportos megoszlásukat az 1. ábrán mutatjuk be. Az
1-2. táblázat szakmacsoport szerinti bontásban tartalmazza a beérkezett válaszokat.

A teljes mintára vonatkozóan az egészségügyi szakdolgozók fele állította, hogy havonta egyszer, míg egyharmada vallotta, hogy hetente egyszer kapta a hálapénzt köszönetnyilvánításként, az egészségügyi szolgáltatás befejezése után, őszinte hálából.

A válaszadók 43\%-a vélte úgy, hogy havonta egyszer fordult elő, hogy soronkívüliség elérése céljából, azért 
2.M táblázat

\begin{tabular}{|c|c|c|c|c|c|c|c|c|c|}
\hline & A hálapénz formái & $=1$ & $=2$ & $=3$ & $=4$ & $=5$ & & & \\
\hline a) & Köszönet szóban vagy írásban & 8 & 12 & 58 & 13 & 1 & & & \\
\hline b) & $\begin{array}{l}\text { Kisebb értékű tárgyi ajándék (például édesség, virág, házi } \\
\text { készítésű szőttes, csemegekosár stb.) }\end{array}$ & 1 & 0 & 15 & 69 & 7 & & & \\
\hline c) & $\begin{array}{l}\text { Nagyobb értékű tárgyi ajándék (például utazási utalvány, } \\
\text { nemesfém ékszer, értékes mútárgy stb.) }\end{array}$ & 6 & 23 & 47 & 14 & 2 & & & \\
\hline d) & Kisebb összegú készpénz (nem több mint 5 ezer forint) & 2 & 2 & 28 & 51 & 9 & & & \\
\hline e) & Nagyobb összegú készpénz (több mint 5 ezer forint) & 3 & 28 & 47 & 13 & 1 & & & \\
\hline \multirow[t]{2}{*}{ f) } & $\begin{array}{l}\text { Társadalmi-szakmai kapcsolatok felajánlása (például tanárként } \\
\text { korrepetálás) }\end{array}$ & 57 & 30 & 5 & 0 & 0 & & & \\
\hline & & & & & & & Átlag & Szórás & Variancia \\
\hline \multirow[t]{2}{*}{ g) } & $\begin{array}{l}\text { Tapasztalatai szerint mekkora összeget/értéket juttat a beteg/ } \\
\text { hozzátartozó - egy hét benntartózkodás esetén (HUF)? }\end{array}$ & & & & & & 12390 & 6269 & 39302620 \\
\hline & $\begin{array}{l}\text { Tapasztalatai szerint mekkora összeget/értéket juttat a beteg/ } \\
\text { hozzátartozó - egy-egy alkalommal (HUF)? }\end{array}$ & & & & & & 6244 & 3578 & 12803975 \\
\hline
\end{tabular}

2.B táblázat

Belgyógyászati jellegú munkahely $(\mathrm{n}=54)$

\begin{tabular}{|c|c|c|c|c|c|c|c|c|c|}
\hline & A hálapénz formái & $=1$ & $=2$ & $=3$ & $=4$ & $=5$ & & & \\
\hline a) & Köszönet szóban vagy írásban & 3 & 4 & 24 & 14 & 8 & & & \\
\hline b) & $\begin{array}{l}\text { Kisebb értékű tárgyi ajándék (például édesség, virág, házi } \\
\text { készítésű szőttes, csemegekosár stb.) }\end{array}$ & 0 & 0 & 12 & 39 & 2 & & & \\
\hline c) & $\begin{array}{l}\text { Nagyobb értékű tárgyi ajándék (például utazási utalvány, } \\
\text { nemesfém ékszer, értékes mútárgy stb.) }\end{array}$ & 6 & 15 & 30 & 2 & 0 & & & \\
\hline d) & Kisebb összegű készpénz (nem több mint 5 ezer forint) & 5 & 1 & 14 & 29 & 4 & & & \\
\hline e) & Nagyobb összegű készpénz (több mint 5 ezer forint) & 7 & 14 & 28 & 3 & 1 & & & \\
\hline \multirow[t]{2}{*}{ f) } & $\begin{array}{l}\text { Társadalmi-szakmai kapcsolat felajánlása (például tanárként } \\
\text { korrepetálás) }\end{array}$ & 24 & 25 & 4 & 0 & 0 & & & \\
\hline & & & & & & & Átlag & Szórás & Variancia \\
\hline \multirow[t]{2}{*}{ g) } & $\begin{array}{l}\text { Tapasztalatai szerint mekkora összeget/értéket juttat a beteg/ } \\
\text { hozzátartozó - egy hét benntartózkodás esetén (HUF)? }\end{array}$ & & & & & & 8917 & 3389 & 11482270 \\
\hline & $\begin{array}{l}\text { Tapasztalatai szerint mekkora összeget/értéket juttat a beteg/ } \\
\text { hozzátartozó - egy-egy alkalommal (HUF)? }\end{array}$ & & & & & & 4146 & 1688 & 2850621 \\
\hline
\end{tabular}

2.GY táblázat

Gyermek/ifjúsági ellátás $(\mathrm{n}=18)$

\begin{tabular}{|c|c|c|c|c|c|c|c|c|c|}
\hline & A hálapénz formái & $=1$ & $=2$ & $=3$ & $=4$ & $=5$ & & & \\
\hline a) & Köszönet szóban vagy írásban & 0 & 5 & 13 & 0 & 0 & & & \\
\hline b) & $\begin{array}{l}\text { Kisebb értékű tárgyi ajándék (például édesség, virág, házi } \\
\text { készítésű szőttes, csemegekosár stb.) }\end{array}$ & 2 & 1 & 5 & 10 & 0 & & & \\
\hline c) & $\begin{array}{l}\text { Nagyobb értékű tárgyi ajándék (például utazási utalvány, } \\
\text { nemesfém ékszer, értékes mútárgy stb.) }\end{array}$ & 11 & 7 & 0 & 0 & 0 & & & \\
\hline d) & Kisebb összegú készpénz (nem több mint 5 ezer forint) & 8 & 1 & 7 & 2 & 0 & & & \\
\hline e) & Nagyobb összegű készpénz (több mint 5 ezer forint) & 14 & 4 & 0 & 0 & 0 & & & \\
\hline \multirow[t]{2}{*}{ f) } & $\begin{array}{l}\text { Társadalmi-szakmai kapcsolat felajánlása (például tanárként } \\
\text { korrepetálás) }\end{array}$ & 14 & 4 & 0 & 0 & 0 & & & \\
\hline & & & & & & & Átlag & Szórás & Variancia \\
\hline \multirow[t]{2}{*}{ g) } & $\begin{array}{l}\text { Tapasztalatai szerint mekkora összeget/értéket juttat a beteg/ } \\
\text { hozzátartozó - egy hét benntartózkodás esetén (HUF)? }\end{array}$ & & & & & & 7889 & 5011 & 25111111 \\
\hline & $\begin{array}{l}\text { Tapasztalatai szerint mekkora összeget/értéket juttat a beteg/ } \\
\text { hozzátartozó - egy-egy alkalommal (HUF)? }\end{array}$ & & & & & & 3778 & 2635 & 6944444 \\
\hline
\end{tabular}

1 = soha $; 2$ = évente egyszer $; \quad 3$ = havonta egyszer $; \quad 4$ = hetente egyszer,$\quad 5=$ gyakrabban, mint hetente egyszer 
adták a hálapénzt, hogy előbb jussanak egészségügyi szolgáltatáshoz; hogy hamarabb vagy soron kívül kerüljenek ellátásra, előbbre kerüljenek a várólistán. A válaszadók $8 \%$-a vallotta, hogy hetente többször is kapott ilyen célból hálapénzt.

Az összes válaszadó 40\%-a szerint mindössze évente egyszer fordult elő, hogy azért adták nekik a hálapénzt, hogy tapasztalt egészségügyi szakdolgozó végezze a beavatkozást. Ez a mútéti és belgyógyászati területen azonos arányokat mutatott, a gyermekellátók esetében kevésbé gyakori volt.

A válaszadók 32\%-a szerint havonta egyszer fordult elő, hogy azért kaptak hálapénzt, hogy (a kötelezőnél) gyakrabban cseréljék az ágynemüt, vagy jobb étel, nagyobb komfort, külön szolgáltatások (például tv, internet) elérése érdekében. A válaszadók 25\%-a szerint ilyen soha nem fordult elö a gyakorlatukban. Ellenben 20\%-uk szerint hetente egyszer előfordult.

Az összes válaszadó alig több mint 6,5\%-a szerint hetente több mint egyszer azért kaptak hálapénzt, hogy a beteg javára az intézményi szabályoktól eltérjenek (például a látogatási időn túl is fogadhassanak látogatót). A válaszadók 27,5\%-a szerint ilyesmi évente egyszer fordult elő, míg 31\%-uk szerint soha. A privilégium megszerzése és a kivételezés a mútéti szakmáknál a válaszadók mintegy 40\%-ának esetében, a gyermekgyógyászati területen mintegy 30\%-uk szerint soha nem volt a hálapénz adásának célja, míg a belgyógyászatban $5,5 \%$ szerint nem fordult elő kivételezésért, de privilégium megszerzése érdekében mindegyik belgyógyászati területen dolgozó válaszadó tapasztalt már ilyet.

A válaszadó egészségügyi szakdolgozók csaknem fele állította, hogy soha nem kapott hálapénzt azért, hogy valamely, jog szerint egyébként is járó jogosultságot ténylegesen elérhetővé tegyen. A válaszadók egynegyede szerint csak évente egyszer fordult elő ilyesmi. A válaszadók mindössze 3,5\%-a tapasztalta, hogy hetente több mint egyszer kapott ilyen célból hálapénzt. Itt a belgyógyászati területen volt a leggyakoribb, míg a gyermekellátásban a legritkább a jelenség.

A válaszadók mintegy fele szerint havonta egyszer fordult elö, hogy a hálapénzt a beteg elhunyta után a hozzátartozó azért adta, amiért nem neki kellett a haldoklás/halál időszakában gondoskodnia a betegről. Azért adta a hozzátartozó, hogy önnön lelkiismeretét megnyugtassa vagy a halottkezelés/temetkezés költségeinek velejárójának tekintette. Hetente egyszer ilyesmi az egészségügyi szakdolgozók 13\%-a szerint történt. Mintegy 18\%-uk szerint sohasem kaptak ilyen célból hálapénzt. A gyermekgyógyászatban kifejezetten ritka ez a motiváció, a másik két területen azonban - leginkább havi gyakorisággal - előfordul.

A válaszadók 40\%-a havonta egyszer szokott hálapénzt visszautasítani. A válaszadók $11 \%$-a hetente több mint egyszer utasít vissza hálapénzt. A válaszadók mintegy 12\%-a hetente egyszer utasít vissza hálapénzt. Ugyanak- kor a válaszadó egészségügyi dolgozók egyötöde sohasem utasított vissza hálapénzt (1. táblázat).

A válaszadó egészségügyi szakdolgozók 57\%-a arról számolt be, hogy mindössze havonta egyszer fordult elö, hogy a hálát szóbeli vagy írásbeli köszönettel fejezték ki irányukban. Mintegy 6,5\%-uk szerint soha nem fordult elő, hogy így köszönték volna meg a munkájukat. Mintegy $5 \%$-uk vallotta azt, hogy hetente több mint egyszer köszönték meg verbálisan a munkájukat.

A válaszadók 71\%-a kap hetente egyszer kisebb értékű tárgyi ajándékot a hála kifejezéseképpen. Mindhárom területen a heti rendszeresség a legtipikusabb gyakoriság. 46\%-uk kap havonta egyszer nagyobb értékü tárgyi ajándékot, feleannyian pedig évente részesülnek ilyenben. A gyermekgyógyászati területen azonban a nagy értékú ajándék kifejezetten ritka, évente legfeljebb egyszer részesül ilyenben a válaszadók 38\%-a. Hetente többször kisebb értékü tárgyi ajándékot 5\%-uk kap (gyermekellátók egyáltalán nem), míg nagyobb értéküt hetente többször kizárólag a sebészeti területen dolgozók jeleztek.

Kisebb összegú készpénzt (nem több mint 5 ezer forintot) a válaszadó egészségügyi szakdolgozók mintegy fele kap hetente egyszer. Hetente többször 7,7\%-uk kap.

Nagyobb összegű készpénzt (több mint 5 ezer forintot) havonta egyszer a válaszadók $45,5 \%$-a szokott kapni. 14\%-uk azt vallotta, hogy sohasem kapott ekkora összegư készpénzt. A gyermekgyógyászatban a kisebb összegü készpénz is inkább havi gyakoriságú, a nagyobb öszszeg kifejezetten ritkaság, még éves szinten is csak a válaszadók egyötöde tapasztalta. A sebészeti területen ugyanakkor a válaszadók fele havi szinten, több mint negyede évente, hetede (14\%) heti szinten részesült ebben. A belgyógyászat mutatói a havi és az éves gyakoriságot tekintve a mútéti szakmákhoz hasonlóak, de a gyakoribb előfordulás jelentősen alacsonyabb arányú.

A válaszadók $58 \%$-a szerint a páciens sohasem ajánlotta fel társadalmi-szakmai kapcsolatait. A válaszadók 35\%-a tapasztalta, hogy évente egyszer történt velük ilyen. A válaszadók egyike sem adott számot arról, hogy hetente egyszer vagy hetente többször történt volna vele ilyesmi. A legkisebb arányt itt is a gyermekgyógyászat képviseli, a legnagyobb arányban a belgyógyászaton fordult elő.

Egy hét benntartózkodás esetén a válaszadók átlagosan 10851 forintot kaptak hálapénzként (a szórás 5606 forint), míg egy-egy alkalommal 5326 forintot (a szórás 3159 forint). A szakterületi megoszlás mindkét formában azonos tendenciát mutat (1. ábra). Az egyhetes benntartózkodást követően adott összegek mutatnak jelentős szórást a mưtéti és a gyermekgyógyászati területen (2. táblázat).

A válaszadók a leggyakrabban a munkahelyen, szokásos munkaidőben kapnak hálapénzt, de a sebészeti és a belgyógyászati szakmák esetében az ügyeleti időben rendszeresen fordul elő a hálapénz adása. Összességében a válaszadók 66\%-a számolt be arról, hogy hetente egyszer munkaidőben kapott hálapénzt, ügyeleti időben a 
válaszadók 30\%-a kapott hetente egyszer. 27,5\%-uk ügyeleti időben sohasem kapott hálapénzt.

A válaszadók (másodállásban) a magánegészségügyben ritkán, évente egyszer kapnak hálapénzt, a sebészeti területen fordul elő elvétve havi gyakoriság.

Az egészségügyi szakdolgozók otthonukban, magánéletükben felkeresve vagy ide küldve igen ritkán (a válaszadók 22\%-a), évente egyszer kaptak hálapénzt, ajándéktárgyat. A gyermekgyógyászatban ez mindösszesen egy esetben fordult elö.

\section{Megbeszélés}

Williams és mtsai szerint a kelet-közép-európai posztkommunista országok közül Magyarországon, Lettországban, Litvániában, Szlovákiában, Bulgáriában és Romániában a legjelentősebb a hálapénzadás az egészségügyben. Míg a nők inkább adnak hálapénzt, mint a férfiak, az álláskeresők, valamint azok, akik korábban rendszerint kifizették a számláikat, kisebb arányban adnak hálapénzt [13].

A magyarországi helyzetet jellemzi, hogy az elmúlt években több gyakorlati lépés is történt az orvosi hálapénz megszüntetéséért. A rezidensek számára bevezetett Markusovszky-ösztöndíjprogram szerződési feltétellé tette a hálapénz el nem fogadását, de ennek ellenőrzése nem történt meg. Ezzel párhuzamosan több orvosi civil szervezet (például a Magyar Rezidens Szövetség), majd a Magyar Orvosi Kamara is célul túzte ki a hálapénz megszüntetését. Az ezzel kapcsolatos orvosiattitűd-vizsgálatok is a hálapénzjelenség elutasításának növekedését mutatják, különösen a fiatalabb orvosgenerációk körében [14]. Minden esetben az érzékelhető, hogy a jelentős béremelést mint alapfeltételt kapcsolták össze a hálapénz megszüntetésével. A 2021. január 1-jén hatályba lépett Eszjt. szabályozása a szakdolgozók számára ezt a feltételt nem teremtette meg, a szakdolgozók évekre szétterített béremelési programja pedig az egészségügyi szakdolgozók számára a társadalmi pozíciójavulást nem alapozta meg, így a hálapénz tilalma számukra akár jövedelmi pozícióvesztéssel is járhat.

Felmérésünk kérdései alapján elemezhetővé vált maga a hálapénz mint az új szabályok szerinti korrupciós jelenség, illetve a hálapénz formái, típusai, melyek közül legálisan csak kis értékü ajándéktárgy adható 2021. januártól.

Az egészségügyi dolgozóknak informálisan adott pénzek osztályozásunk szerint a nemzetközi szakirodalom alapján:

\section{1) Hálapénz}

A köszönet kifejezése, önkéntes, de az egészségügyi dolgozók általában elvárják [15].

\section{2) Nem hivatalos pénzfizetés (unofficial payment)}

Nem hivatalos hozzájárulás az egészségügyi költségekhez, valamint többletszolgáltatásért adott pénz. Illegális, de az egészségügyi rendszer múködéséhez hozzátartozik, így nem büntetik [16].

\section{3) Hongbao}

Kínában megszokott pénzfizetés (piros borítékban) az egészségügyi dolgozó szívességéért. Legális, így nem büntetik [17].

\section{4) Ajándék}

Az egészségügyi dolgozó által nem elvárt, a hála őszinte kifejezésének számító ajándék. Jogszerű és erkölcsös, így nem büntetendő [18].

\section{5) Asztal alatt (pult alatt) fizetés (under-the-table pay-} ment)

Pénz átadása, amelyet nem tüntetnek fel az adóbevallásban. Ha felderítik, akkor büntetik [19].

\section{6) Vesztegetési pénz}

Kötelességszegésért vagy befolyásolási céllal nyújtott vagy ígért jogtalan előny. Bûncselekménynek minősül [20].

Ezen hat kategóriából jogi szempontból a vesztegetési pénz és az ajándék érvényesül Magyarországon a leggyakrabban, és a kifizetések a beteg és az orvos együttmúködésével sok esetben a Kúria által korábban legálisnak elismert, utólagosan fizetett hálapénz formájában zajlanak. 2021. január 1-je óta azon informális fizetés, amely nem minősül 8370 forintot meg nem haladó értékű ajándéktárgynak, vesztegetési pénznek minősül. Az azt adó páciens vagy hozzátartozója aktív vesztegetésért, az azt elfogadó egészségügyi dolgozó passzív vesztegetésért felel. Szakosított nyomozó szerv (Nemzeti Védelmi Szolgálat, Korrupcióellenes Főosztály) felderítési feladatává tették a bűncselekmények feltárását, amely szerv - a sajtónak adott tájékoztatás szerint - kizárólag az elfogadó orvosokkal szemben fog eljárni.

A hálapénz korábban ismert jogfogalma ezzel megszúnik. Annak adójogi vonzata is kivezetésre került a jogszabályokból, azaz a 2020-as adóévben kell utoljára az erre nevesítetten feltüntetett sorba beírni a hálapénzbevételt. Nem egyértelmú, hogy kell-e adót fizetni az ajándék után, mert az ajándék elfogadása egyébként adóköteles.

A szakdolgozók körében a hálapénz ugyanúgy átszövi az ellátórendszert, mint az orvosok körében, bár az egy ellátóra jutó összeg nyilván jelentősen kisebb. Felmérésünk szerint az alkalmanként adott ápolói hálapénz az elmúlt 7 év alatt a KSH által mért értékhez [1] képest 1,5-6-szorosára növekedett. Az összegszerúség vizsgálatakor nehezíti az ápolóhelyzet megítélését, hogy míg az orvos személyesen kapja a hálapénzt, addig az ápolóknál az osztályos ápolói közösség tagjai közötti felosztásról is gyakran beszámolnak, azaz az egy fơre jutó hálapénz nehezebben kalkulálható. Nyilvánvaló, hogy a választott/ fogadott szülésznő esetében ez a csoporttal történő 


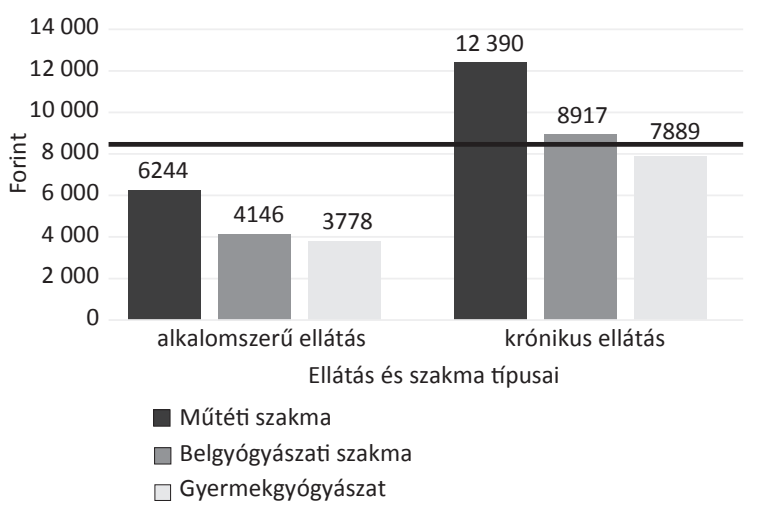

2. ábra kapták (1. ábra). Ez jól mutatja, hogy a mútéti beavatkozások kapcsán a páciensek erôsebben kiszolgáltatva érzik magukat, akár az egészségüket érintően, akár az ellátás körülményeit illetően, és felismerik, hogy az ápolók fizikai terhelése itt a legerőteljesebb. Ez a jelenség leképezi az orvosi hálapénznél észlelt tendenciát, mely szerint a mütéti szakterületek orvosai magasabb hálapénzösszegekkel számolhatnak. Éppen ezért az új tilalmak a mútéti területen fejtik ki hatásukat a legérzékenyebben.

A hálának a kezelést követő, köszönet jellegű kifejezése a gyermekellátók esetében volt inkább jellemző, a belgyógyászati és mútéti területeken az egyéb, eddig is illegális motiváció lényegében ugyanolyan gyakran fordult elő. A 2021-től hatályos jogalkotási fordulat értelmében ajándéktárgy átadása csak a kezelést követően, azaz köszönetnyilvánításként lehetséges, pénzt egyáltalán nem törvényes adni. Felmérésünk alapján ez a szabály a gyermekgyógyászatban jelenti a legkisebb változást, hiszen itt volt jellemző a köszönet, és itt voltak a legalacsonyabbak a pénzösszegek.

A halálesetekhez kapcsolódó hálapénzadási hajlam a belgyógyászatban volt a leginkább jelen, feltehetően a hosszabb haldoklás, krónikus- vagy hospice-ellátás indokolta.

Nagyobb problémát jelent a jövedelmekbe informálisan belekalkulált hálapénzbevétel. Egy eddig alkalmanként több ezer vagy havi szinten több tízezer forint hálapénzt legálisan elfogadó egészségügyi szakdolgozó a betegektől kapott ajándéktárgyból (vágott virág, csokoládé, kéziszőttes stb.) nem tudja kompenzálni a kieső bevételét, ami az egészségügyi szakdolgozók családjának anyagi helyzetét is megnehezíti. Ráadásul a belgyógyászati és mútéti területeken a kivételezés és a privilégium megszerzése is fontos helyet kapott a betegek motivációjában. Tehát a beteg számára elmaradó „többletszolgáltatás" a betegelégedettséget csökkentheti, míg a hálapénz elmaradása a szakdolgozói elégedetlenség forrásává válhat.

A szakdolgozók által is felismert korrupció a legkevésbé a mütéti területeken volt jelen; az elmúlt évek néhány szabálya állhat a háttérben, például a nyilvános várólistarendszer a mútéti osztályos felvételek, az idópont-egyeztetések tekintetében transzparensebb rendszer kialakulását eredményezte. Az időtényező (hamarabb elvégzett beavatkozás) érdekében adott juttatást illetően a válaszok szerint hasonló következtetésre jutunk: a mútéti területeken havonta vagy ennél gyakrabban adtak hálapénzt a válaszadók kétharmada szerint, míg a belgyógyászati területen a válaszadók mintegy $90 \%$-a, a gyermekgyógyászatban egyhatoda (16\%) számolt be erról.

A hálapénz helyettesítő vagy kiegészítő formája lehet a társadalmi-szakmai kapcsolatok felajánlása, protekció ajánlása. Az egészen egyszerú segítségtől a büntető jogszabályokban is megjelenő befolyással üzérkedésig ez a szívességfelajánlás sokféle lehet. Ez kifejezetten ritkán fordul elő. Nem zárható ki, hogy az új szabályozás ennek 
a nem tárgyiasuló hálapénzformának a megerősödését eredményezi.

Összességében tehát a tényleges korrupciós célú vagy annak nagyobb veszélyét magában rejtő céllal és módon adott hálapénz az egészségügyi szakdolgozói szférában ugyan jelen van, de nem jellemző.

A hálapénz visszautasítása tekintetében kapott válaszok alapján a válaszolók mintegy 10-15\%-a soha nem utasított el hálapénzt, a visszautasítás gyakorisága szerint a gyermekgyógyászatban ez kifejezetten gyakori, a mútéti szakmákban is általános, míg a belgyógyászati szakterületeken kifejezetten ritkább.

A hálapénz tárgyi ajándék formájában is jelen van a magyar egészségügyben, akár nagyobb értékben is. Jellemzően a gyakoribb és nagyobb értékek a sebészeti területen jelennek meg. Az új szabályozás ezt a létező jelenséget erősíti meg, különösen az akutellátók javára, akik ellátási esetenként részesülhetnek benne, míg a hosszú távú ellátásnál kéthavi gyakorisággal fogadható el juttatás. Ezzel egyébként a szakdolgozói hálapénzkülönbségek - kis változással - konzerválódnak.

A magánellátásban a hálapénzjelenség jelen van, de nem olyan gyakorisággal, mint a közszolgáltató egészségügyben. A betegek és hozzátartozóik döntően a szakdolgozók munkavégzésének helyén és idejében adják a hálapénzt vagy ajándékot. Ezeket a magától értetődő megállapításokat mint kiindulási helyzetet kell rögzítenünk, mert az új törvényi szabályozás következtében nem kizárt, hogy a betegek (és/vagy az ellátók) a hálapénzjelenséget megpróbálják kivinni, kiterelni a közszolgáltató intézményből, és az egészségügyi dolgozó egyéb tevékenysége során vagy otthonában, mintegy magánéleti kapcsolaton (barátság) alapuló ajándék vagy más jogcímen adott juttatás formájában továbbra is fenntartani.

\section{Következtetés}

A hálapénz a 2021-tôl hatályos jogalkotási fordulat előtt is jelen volt a magyarországi egészségügyi szakdolgozók körében, és várhatóan a jogalkotási fordulat után is jelen lesz. Felmérésünk adatai szerint a szakdolgozói hálapénz sok tekintetben azonos jellemzőket mutat az orvosi hálapénz jelenségével. Esetünkben a legkevésbé korrumpált és legkevésbé érintett terület a gyermekellátás volt, míg az egyéb területeken még a magánellátásban is jelen van. A jövőben a hangsúly várhatóan inkább az ajándéktárgyak felé fog eltolódni, de a dolgozói csoportok közötti eloszlás aránytalanságai fennmaradnak. Az eddig pénzben jelentős fizetéskiegészítést elérők számára az összegszerü korlát és a pénz tilalma is veszteséget jelent, mert a válaszok szerint a törvényi limit fölött vannak a hálapénzjuttatásaik. Mindazonáltal nem lehetetlen, hogy valamiféle pénzbeli juttatás is fennmarad az egészségügyi szakdolgozók körében, amelynek tényleges átadása kihelyeződhet a munkahelyen és munkaidőn kívülre. A kisebb értékú ajándéktárgyak adását a jogalkotó továbbra is lehetővé teszi. A hála meg nem engedett mértékű és formájú kifejezését nem könnyú jogalkotási aktussal eliminálni. Az eddigi kommunikáció csak az orvosok ellenőrzését és felelősségre vonását vetítette előre, a szakdolgozókra vonatkozó szándékok nem ismertek.

Megállapítható, hogy a hálapénz „betiltásához” vezető jogszabály elókészítése során az orvosokat érintő adatok, elemzések rendelkezésre álltak, de átfogó, szakdolgozói elemzést nem ismerünk. A büntető törvénykönyvi tiltás ugyanakkor minden egészségügyi szolgálati jogviszonyban álló dolgozóra és az ellátott betegekre és hozzátartozóikra egyaránt vonatkozik. Szükséges lenne egy olyan társadalompolitikai komplex program és kommunikációjának kidolgozása, amely segíti a hálapénz magyarországi felszámolását, és képes a társadalmi, valamint egészségügy-szakmai attitűd megváltoztatására.

Anyagi támogatás: A kézirat megírása anyagi támogatásban nem részesült.

Szerzôi munkamegosztás: J. M.: A kérdőíves kutatás eredményeinek kiértékelése és a cikk megírása. K. É. M.: A kutatás szakmai felügyelete és a cikk megírása. A cikk végleges változatát mindkét szerző elolvasta és jóváhagyta.

Érdekeltségek: A szerzőknek nincsenek érdekeltségeik.

\section{Köszönetnyilvánítás}

Köszönjük a Szegedi Tudományegyetem Ápolási Igazgatóságának a válaszadók eléréséhez nyújtott segítségét.

\section{Irodalom}

[1] Hungarian Central Statistical Office. Tip and informal payment. [Borravaló és hálapénz.] Központi Statisztikai Hivatal. Statisztikai Tükör 2015/16. Available from: https://www.ksh.hu/ docs/hun/xftp/stattukor/halapenz.pdf [accessed: February 25, 2021]. [Hungarian]

[2] Antal O, Baba C. Informal payments in Romania: the medical personnel point of view. A preliminary study. In: Hințea CM, Moldovan BA, Radu BV, et al. (eds.) Transylvanian International Conference in Public Administration. Cluj-Napoca, Romania, 2-4. November 2017. Accent, Cluj-Napoca, 2018; pp. 33-44.

[3] Zandian H, Esfandiari A, Sakha MA, et al. Strategies to reduce informal payments in health systems: a systematic review. East Mediterr Health J. 2019; 25: 914-922.

[4] Horodnic AV, Mazilu S, Oprea L. Drivers behind widespread informal payments in the Romanian public health care system: From tolerance to corruption to socio-economic and spatial patterns. Int J Health Plann Manage. 2018; 33: e597-e611.

[5] Arsenijevic J, Pavlova M, Groot W. Out-of-pocket payments for health care in Serbia. Health Policy 2015; 119: 1366-1374.

[6] Radin, D. Does corruption undermine trust in health care? Results from public opinion polls in Croatia. Soc Sci Med. 2013; 98: 46-53.

[7] Riklikiene O, Jarasiunaite G, Starkiene L. Informal patient payments in publicly financed healthcare facilities in Lithuania. Scand J Public Health 2014; 42: 488-496. 
[8] Baji P, Gulácsi L. The situation is unchanged - The results of a representative questionnaire survey about the customs and opinions of the Hungarian population concerning informal payments. [A helyzet változatlan - Egy reprezentatív kérdő́ves felmérés eredményei a magyar lakosság hálapénz-fizetési szokásairól és a hálapénz megítéléséről.] Egészségügyi Gazdasági Szemle 2012; 50(4): 30-36. [Hungarian]

[9] Holmberg S, Rothstein B. Dying of corruption. Health Econ Policy Law 2011; 6: 529-547.

[10] Williams CC, Horodnic AV. Explaining informal payments for health services in Central and Eastern Europe: an institutional asymmetry perspective. Post-Communist Economies 2018; 30: $440-458$.

[11] Balázs P. The historic master key to get rid of medical doctors' informal payment. [Az orvosi hálapénz megoldásának történelmi kulcsa.] Orv Hetil. 2019; 160: 50-56. [Hungarian]

[12] Julesz M. Telemedicine and COVID-19 pandemic. [A telemedicina és a COVID-19-világjárvány.] Információs Társadalom 2020; 20(3): 27-38. [Hungarian]

[13] Williams CC, Horodnic IA, Horodnic AV. Who is making informal payments for public healthcare in East-Central Europe? An evaluation of socio-economic and spatial variations. East J Eur Studies 2016; 7: 49-61.

[14] Torzsa P, Csatlós D, Eôry A, et al. Opinions of Hungarian family physicians and residents on vocation and informal payment.
[Hivatással és hálapénzzel kapcsolatos vélekedések a magyarországi családorvosok és családorvos rezidensek körében.] Orv Hetil. 2016; 157: 1438-1444. [Hungarian]

[15] Julesz $M$. The legal history of gratitude payments to physicians in Hungary. J Eur History Law 2018; 9(1): 149-157.

[16] Simkhada P, van Teijlingen E, Sharma G, et al. User costs and informal payments for care in the largest maternity hospital in Kathmandu, Nepal. Health Sci J. 2012; 6: 317-334.

[17] Ensor T. Informal payments for health care in transition economies. Soc Sci Med. 2004; 58: 237-246.

[18] Chan CSc, Yao ZL. A market of distrust: toward a cultural sociology of unofficial exchanges between patients and doctors in China. Theor Soc. 2018; 47: 737-772.

[19] Schaaf M, Topp SM. A critical interpretative synthesis of informal payments in maternal health care. Health Policy Plan. 2019; 34: 216-229.

[20] Pourtaleb A, Jafari M, Seyedin H, et al. A pervasive review study on informal patient payments. Int J Med Res Health Sci. 2018; 7: $57-65$.

(Julesz Máté dr., Szeged, Kossuth L. sgt. 40., 6724 e-mail: julesz.mate@med.u-szeged.hu)

\section{„Duplex fit bonitas simul accessit celeritas." (Kétszeres a jóság, ha gyorsasággal párosul.)}

A cikk a Creative Commons Attribution 4.0 International License (https://creativecommons.org/licenses/by/4.0/) feltételei szerint publikált Open Access közlemény, melynek szellemében a cikk bármilyen médiumban szabadon felhasználható, megosztható és újraközölhető, feltéve, hogy az eredeti szerző és a közlés helye, illetve a CC License linkje és az esetlegesen végrehajtott módositások feltüntetésre kerülnek. (SID_1) 